\title{
Prickle-Like Protein 1
}

National Cancer Institute

\section{Source}

National Cancer Institute. Prickle-Like Protein 1. NCI Thesaurus. Code C126760.

Prickle-like protein 1 (831 aa, $94 \mathrm{kDa}$ ) is encoded by the human PRICKLE1 gene. This protein is involved in embryonic morphology. 